\title{
EFFECT OF STOCK MARKET DEREGULATION ON STOCK MARKET PERFORMANCE IN NIGERIA (1986 - 2018)
}

\author{
BENSON Emmanuel PhD ${ }^{1 *}$, AJAM Peter Ngbede ${ }^{2}$, EPOR Simon Okaja ${ }^{3}$ \\ ${ }^{* 1,2}$ Department of Accounting and Finance, University of Agriculture, Makurdi, Benue State \\ ${ }^{3}$ Department Accounting and Finance, Nnamdi Azikiwe University Akwa, Anambra State
}

\section{*Corresponding Author: -}

\begin{abstract}
: -
The aim of this study is to empirically investigate the effect of Stock Market Deregulation on Stock Market Performance in Nigeria. The study used secondary data from the Statistical Bulletin of Central Bank of Nigeria. Expost factor research designs was adopted for this study. The study is designed to cover thirty two years, from 1986 to 2018. The study relied on data from Central Bank of Nigeria statistical bulletin, covering thirty one years from 1986 to 2018. Fully Modified Ordinary Least Square regression model has been constructed, the goodness of fit of the model is confirmed using R-squared. The statistical significance of the estimated parameters is checked by an F-test of the overall fit, followed by the probability value of the individual parameters. Interpretations of these diagnostic tests rest heavily on the model assumptions. The results of the multicollinearity, heteroscedasticity provides the robustness check for the mode of the study. The hypotheses formulated was tested by means of the probability values of estimates of regression analysis. Thus, from the random sample from the population, we estimate the population parameters and obtain the sample linear regression model. The result of the regression analysis revealed that stock market deregulation proxied by equities (EQUI) has negative and statistically insignificant effect on stock market performance in Nigeria. A 1 percent increase in equity will reduce stock market performance by $29.0 \%$. Also the result indicates that interest rate has a negative and statistically insignificant effect on stock market performance in Nigeria. On the other hand, exchange rate was found to have positive but statistically significant $(p<0.05)$ effect on stock market performance in Nigeria. The value of the R-squared (0.714) indicates that about $51.4 \%$ of the total variation in the dependent variable is explained by the independent variables. It was concluded that further deregulation of the market will weaken the market and therefore should be avoided. It was recommended among that evolvement of policies that will bring down the rate of exchange and interest rate in the view of making the naira valuable relative to the dollar and making the cost of capital affordable.
\end{abstract}

Keywords: Stock Market, Deregulation, performance, Nigeria

\section{() (\$) (1)}




\subsection{INTRODUCTION}

The stock market provides equity and a direct form of finance to potential investors for economic purposes. This role enables it to function as a critical long-term lubricant in the economic growth process. The performance of the stock market is in addition often considered an essential barometer for measuring a country's economic strength and development. Thus, an economy with an active capital market may have its vital stock market index regularly used as a guide in the measurement of changes in the general level of economic activities within the concerned economy. Another major role of the stock market as an economic institution is that it enhances the efficiency of capital formation and allocation of resources. It is therefore expected that every active stock market will facilitate the availability of long-term capital for economically productive activities and this remains a key requirement for economic growth and development. The stock market also provides a means by which the capital needed for efficient or effective growth in the economy is made available. Stock markets are in addition regarded as a necessary tool for economic growth and development as they provide listed companies the platform to mobilize much needed capital for the long-term investment needs of businesses. This also encourages surplus spending economic agents to save thereby increasing the saving rate as well as directly stimulating more investments and consequently bringing additional investment income to the owners of funds.

There is therefore a need for Nigeria to strengthen its equity market, promote financial stability and create economic and political balance. In order to do so, Nigeria needs to strengthen financial cooperation with other countries of the world, cross- border activities within the region need to be improved. One of the ways to improve cross- border activities is by removing legal or informal restrictions. Specifically, it is the government's decision on the removal of legal or informal restrictions on capital flows (Bilson, Brailsford, and Hooper, 2001), which is termed stock market deregulation. Stock market deregulation, the main focus of this study, would theoretically allow for greater capital inflows, which in return improve the performances of the liberalizing Nigeria's stock market.

Based on the theoretical prediction of standard International Asset Pricing Model (IAPM), the deregulation of stock market would increase the equity price index of emerging markets like Nigeria and therefore results in an increase in equity market returns. Such result is expected due to an increase in efficiency and a decrease in the cost of equity capital upon the openness of the market to investors. An increase in net capital inflows would reduce the risk-free rate, increase the stock market liquidity and facilitate risk sharing. Studies that analyze the effect of stock market deregulation find that their results are consistent with the prediction of the model (Bilson, Brailsford, and Hooper, 2000; Tai, 2007 and Iwata \& Wu, 2009). In recognition of the acclaimed catalytic effect of stock market deregulation on stock market performance, this study investigates whether stock market deregulation has significant effect on the performance of stock market in Nigeria. Also, most of the empirical studies reviewed in this work did not use macroeconomic variables (exchange rate and interest rate), hence this study included them as control variables. This research therefore intends to fill this gap by further analyzing any differences in the effect of stock market deregulation on stock market performance. The main objective of this study is to examine the effect of stock market deregulation on stock market performance in Nigeria between 1986 and 2016. The specific objectives are to; Investigate the effect of returns on equity on stock market performance in Nigeria, examine the effect of exchange rate on stock market performance in Nigeria and ascertain the effect of interest rate on stock market performance in Nigeria.

\subsection{Literature Review}

\section{Theoretical Underpinning Financial Liberalization theory}

The classical and neoclassical economic postulations summarized in studies by Schumpeter, (1912); Goldsmith (1969); McKinnon (1973); Shaw (1973 and Pagano (1993) among others, argued that financial development has a strong correlation with growth. The classical school argues that under the assumption of a well-functioning market, financial liberation enhances efficiency in resource allocation, promote competition which results in competitive prices for goods and services.

McKinnon (1973) Shaw (1973), leveraging on the work of Schumpeter (1911), the financial liberalization thesis, contending that government regulations hold back the quantity and quality of investment. For Pagano (1993) and King \& Levine (1993) who propounded the endogenous growth model state that financial intermediation has a significant positive effect on the steady growth and that government intervention in the financial system has a negative effect on the equilibrium growth rate. The financial liberalization thesis attributed the pitiable performance of investment and growth in developing countries to interest ceiling, high reserve requirements and quantitative restrictions in credit allocation. According to this theory, the restrictions were sources of financial repression, and the main symptoms are low savings, credit rationing and low investment in that economy. Thus the need for financial liberalization which frees financial market from any intervention and allow the market forces of demand and supply determined the allocation of credit in an efficient manner (Ighosewe \& Akpokerere, 2015). The theory therefore, is against active participation of government in economic activity and argues that the role of government if any should be limited to maintenance of law and order and the creation of relevant institutions for the efficient functioning of the free market system.

\section{Rational Expectations Theory}

Rational expectations theory states that the players in an economy will act in a way that conforms to what can logically be expected in the future. That is, a person will invest, spend, etc. according to what he or she rationally believes will happen in the future. Although this theory has become quite important to economics, its utility is doubtful. For example, an investor thinks a stock is going to go up, and by buying it, this act actually causes the stock to go up. This same 
transaction can be framed outside of rational expectations theory. An investor notices that a stock is undervalued, buys it, and watches as other investors notice the same thing, thus pushing the price up to its proper market value. This is the problem with Nigerian stock market trying to restore market confidence since after the global financial crunch. The general expectation of Nigerian investors is pessimistic and hence the market is dragging irrespective of the innovations introduced by the regulatory agency and the Nigerian stock exchange (Okonkwo, Ogwuru and Ajudua, 2014).

\section{Conceptual Framework}

\section{Concept of Stock Market and Stock Market Deregulation}

Companies issue shares on the stock exchange to raise money to procure fixed assets or to diversify into new business venture rather than using the fund realized for recurrent expenditure. Shareholding has been explained as simple possession of a paper asset which carries with it a hold on the capital and income of the company and a share in the management of the company through voting right proportional to number of shares held (Hoesli, \& McGregor, 2000). A veiled differentiation of common and preference stocks have been availed, that the term "common stock" do not convey a precise meaning, and is usually used in reference to stocks or shares that are given no special preference in the event of dividend payment or bankruptcy, and where the holders receive certificate with a stated value of cash share called "par value" which is normally lower than the market value of the stock (Ross, Westerfiled \&Jeffrey 2005).

It is the common stocks of a listed company that can be bought or sold freely on the stock exchange market and the reward for ownership is paid in the form of a dividend (Ross, Westerfiled \& Jeffrey 2005). Dividend payment however is not guaranteed in either real or nominal terms to shareholders, but depends primarily on the ability of the company to make profits and the policy of its directors to either pay dividends or retain profits (Hoesli, \& McGregor, 2000). Stock market deregulation according to Auzairy, Ahmad and Ho (2011) is defined as removal of legal and informal restrictions in order to enhance efficiency of the market. It is a deregulation that takes place after the first stock market deregulation. It is normally imposed on specific sector(s) and for a smaller percentage change of foreign ownership.

\section{Concept of Stock Market Performance}

Stock Market Performance is the indicator of the stock market as a whole or of a specific stock. It gives signal to the investors about their future moves. The movement in the price of a stock and the indexes gives the idea of the near future trend of the stock, sector or the economy as a whole. As financial domain is the most important one of an economy, so the stock market performance works as an indicator of the overall health of the economy (Economywatch, 2010).

Stock Market Indexes typically gives the overall performance of the market or of a specific sector. Indexes reflect the performance of the economy or a sector in entirety. Stock Prices are an indicator of the performance of the stock. If the price of a particular stock is rising then it is perceived that it has certain positive news or signals. But, if it decreases then there must be some negative news regarding its performance, which is generating negative signals to the market. Hence, the stock price movement and index movements show the general economic trend of a country (Economywatch, 2010).

\section{Empirical Review}

Adam and Tweneboah (2008) examined the impact of macroeconomic variables on stock prices in Ghana using quarterly data from 1991 to 2007 . They examined both the long- run and short-run dynamic relationships between the stock market index and the economic variables-inward foreign direct investment, Treasury bill rate, consumer price index, average oil prices and exchange rates using co-integration test, Vector Error Correction Model (VECM). They found that there is co-integration between macroeconomic variable and stock prices in Ghana indicating long-run relationship. The VECM analysis shows that the lagged values of interest rate and inflation have a significant influence on the stock market. Also, the inward foreign direct investments, oil prices, and the exchange rate demonstrate weak influence on price changes.

Serkan (2008) investigates the role of macroeconomic factors in explaining Turkish stock returns. He employed macroeconomic factor model from the period of July 1997 to June 2005. The macroeconomic variables considered are growth rate of industrial production index, change in consumer price index, growth rate of narrowly defined money supply, change in exchange rate, interest rate, growth rate of international crude oil prices and return on the MSCI World Equity Index. He found that exchange rate, interest rate and world market return seem to affect all of the portfolio returns, while inflation rate is significant for only three of the twelve portfolios. Also, industrial production, money supply and oil prices do not appear to have significant effect on stock returns in Turkey.

Demirgue-kunt and Levine (1996) using data from 44 countries for period 1986 and 1993 found that different measures of stock exchange size are strongly correlated to other indicators of activity levels of financial, banking, non-banking institutions as well as to insurance companies and pension fund. They concluded that countries with well- developed stock markets tend to also have well developed financial intermediaries. Again, Demiurgue-kunt and Masksimovic (1998) have shown and re-emphasized the complementary role of stock market and banks that they were not rivals or alternative institutions using 30 countries from 1980 to 1991. Levine and Zervos (1998) used pooled crossed country time series regression of 47 countries from 1976 to 1993 to evaluate whether stock market liquidity is related to growth, capital accumulation and productivity. They towed the line of Demiurgue-kunt and Levine (1996) by conglomerating measures such as stock market size, liquidity and integration with world market, into index of stock market development. The rate of Gross Domestic Product (GDP) per capital was regressed on a variety of variables designed to control for initial conditions, political instability, investment in human capital and macroeconomic condition and then 
included the conglomerated index of stock market development. They found empirically that the measures of stock market liquidity were strongly related to growth capital accumulation and productivity while stock market size does not seem to correlate to economic growth.

Afees and Kazeem (2010) examined the causal linkage between stock market and economic growth in Nigeria between 1970 and 2004. The indicator of the stock market development used are market capitalization ratio, total value traded ratio and turnover ratio while the growth rate of gross domestic product is used as proxy for economic growth, using the Granger causality (GC) test, the empirical evidence obtained from the estimation process suggests a bidirectional causality between turnover ratio and economic growth, an unidirectional relationship from market capitalization to economic growth and no causal linkage between total value traded. The result of the causality test is sensitive to the choice of variable used as proxy for stock (capital) market. Overall, the result of the G.C test suggested that capital market drive economic growth.

Edame and Okoro (2010) carried out research on The Impact of Capital Market and Economic Growth in Nigeria. Time series data obtained for the period 1970-2010 from Central Bank of Nigeria (CBN) and Nigeria Stock Exchange (NSE) were analyzed using regression. The data obtained were fitted to the equation by ordinary least- square (OLS) regression method. The growth rate of Gross Domestic Product (GDP) per capita was regressed on a variety of capital market variables such as market capitalization, all share index, number of deals, value of transactions and interest rate. From the result obtained, capital market has positive and significant impact on economic growth in Nigeria. The capital market variables captured in the model such as market capitalization, number of deals and value of transactions were all positive and significant in promoting economic growth in Nigeria. It is important that the government should implement policies that will make the market more efficient and re-position it for growth within the Nigerian economy.

Elumilade and Asaolu (2006) examined the relationships between stock market capitalization rate and interest rate. Time series data obtained for the period 1981-2000 from Central Bank of Nigeria (CBN) and Nigeria Stock Exchange (NSE) were analyzed using regression. The data obtained were fitted to the equation by ordinary least- square (OLS) regression method. Results showed that the prevailing interest rate exerts positive influence on stock market capitalization rate. Government development stock rate exerts negative influence on stock market capitalization rate and prevailing interest rate exerts negative influence on government development stock rate. The study further revealed information as very important to capital market development. It was therefore recommended that the operators of the Nigeria capital market should raise the level of awareness so that investors will be abreast with the happenings in the market.

Oluwatoyin and Ocheja (2009) examine the impact of stock market earnings on income of the average Nigerian using time series data covering the period 1980-2007. Applying co-integration and error correction modeling to stock market performance and per capital income time series data, the findings indicated the separate roles played by the primary capital market and the secondary capital market in the growth of stock market earnings that has impacted positively on Nigerian per capita income. By and large, the evidence from this study revealed that while activities in the secondary capital market tend to grow the stock market earnings through its wealth effect that of the primary market ironically did not.

Levine and Zervos (1996) examines whether there is a strong empirical association between stock market development and long- run economic growth. The study used pooled cross-country time-series regression of forty- one countries from 1976 to 1993 to evaluate this association. The study took the line of Demirguc-Kunt and Levine (1996) by conglomerating measures such as stock market size, liquidity, and integration with world markets, into index of stock market development. The growth rate of Gross Domestic Product (GDP) per capita was regressed on a variety of variables designed to control for initial conditions, political stability, investment in human capital, and macroeconomic conditions; and then include the conglomerated index of stock market development. The finding was that a strong correlation between overall stock market development and long-run economic growth exist. This means that the result is consistent with the theories that imply a positive relationship between stock market development and economic growth.

Arestis, Demetriades and Luintel (2001) examined the relationship between stock market development and economic growth through quarterly time-series data for five developed economies while controlling for the effect of banking system and market volatility. These countries are: the USA, the UK, France, Germany, and Japan. The period covered 1968-1998 although the data span is different for different countries in the sample. The results reveal that in Germany, there is evidence of bidirectional causality between banking system development and economic growth. The stock market on the other hand is weakly exogenous to the level of output. In the USA, financial development does not cause real GDP in the long-run. Japan exhibits bidirectional causality between both banking and stock market variables and the real GDP, while in the UK the results indicate evidence of unidirectional causality from banking system to stock market development in the long-run, but the causality between financial development and economic growth in the longrun is very weak. The evidence in France suggests that in the long-run both the stock market and banking system contribute to real GDP but the contribution of the banking system is much stronger.

Dritsaki and Dritsaki-Bargiota (2005) used a trivariate VAR model to examine the causal relationship between stock, credit market and economic growth for Greece. Through monthly data covering the period 1988:1- 2002:12, their results reveal unidirectional causality from economic development to stock market and bidirectional causality between economic developments and the banking sector. The paper establishes no causal relationship between stock market function and banking sector.

Osinubi (1998) examines whether stock market promotes economic growth in Nigeria between the period 1980 and 
2000. The study employed the Ordinary Least Squares (OLS) regression technique as the method of data estimation. The regression results, confirms that there exists positive relationship between the economic growth and the measures of stock market development used. However, these relationships are statistically insignificant. This in essence means that the effect of stock market on economic growth is weak and insignificant.

\subsection{Research Methodology}

Ex-post factor research designs was adopted for this study. It examines how an independent variable, prior to the study affects a dependent variable. The study is designed to cover thirty-two years, from 1986 to 2018. The study relied on data from Central Bank of Nigeria statistical bulletin, covering thirty-one years from 1986 to 2018.

The hypothesis formulated was tested by means of the estimates of regression analysis. Thus, from the random sample from the population, we estimate the population parameters and obtain the sample linear regression model:

$$
\hat{y}_{i}=\beta_{\mathrm{o}}+\beta_{1} x_{i} \ldots+\beta_{\mathrm{n}} x_{n}
$$

The residual, $e i=y i-\hat{y} i$, is the difference between the value of the dependent variable predicted by the model, $\hat{y} i$, and the true value of the dependent variable, $y i$. Fully Modified Ordinary least squares (FMOLS) was used to obtain parameters estimates that minimize the sum of squared residuals, SSE:

$$
\mathrm{SSE}=\sum_{i=1}^{n} e_{i}^{2}
$$

Minimization of this function results in a set of normal equations, a set of linear equations in the parameters, which are solved to yield the parameter estimators, $\beta_{0}, \beta_{1}$ :

$$
\beta_{1}=\frac{\sum\left(x_{i}-\bar{x}\right)\left(y_{i}-\bar{y}\right)}{\sum\left(x_{i}-\bar{x}\right)^{2}} \text { and } \beta_{0}=\bar{y}-\beta_{1} \bar{x}_{\Lambda}
$$

Where $x$ is the mean (average) of the $x$ values and $y$ is the mean of the $y$ values. Under the assumption that the population error term has a constant variance.

Where

$$
S M R=\alpha_{0}+\alpha_{1} E Q U I+\alpha_{2} E X R+\alpha_{3} I N T R+\varepsilon
$$

$\alpha_{0}=$ intercept or constant term

$\alpha_{1}-\alpha_{3}-=$ the parameter estimates of the model and

$\varepsilon=$ the error terms

A priori expectation $\alpha_{1}>0$ and $\alpha_{2}$ and $\alpha_{3}<0$

Under the further assumption that the population error term is normally distributed, the estimated standard errors are sed to create confidence intervals and conduct hypothesis tests about the population parameters. Once the Fully Modified Ordinary Least Square regression model has been constructed, the goodness of fit of the model is confirmed using Rsquared. The statistical significance of the estimated parameters is checked by an F-test of the overall fit, followed by the probability value of the individual parameters. Interpretations of these diagnostic tests rest heavily on the model assumptions. Although examination of the residuals can be used to invalidate a model, the results of the ulticollinearity, heteroscedasticity provides the robustness check for the mode of the study. The decision rule for accepting or rejecting the hypotheses of the study is based on the probability value of the estimate. Thus, If the probability value of bi [ $p$ (bi) > the critical value] we accept the null hypothesis, that is, we accept that the estimate bi is not statistically significant at the 5\% level of significance. If the probability value of bi [p (bi) <critical value] we reject the null hypothesis, in other words, that is, we accept that the estimate b1 is statistically significant at the 5\% level of significance

\subsection{Results And Discussion}

The various descriptive statistics that are discussed are minimum, maximum. Mean and standard deviation for all variables of the study. These are contained in Table 1.

Table 1: Descriptive Statistics

\begin{tabular}{lcccc}
\hline & SMR & EQUI & EXR & INTR \\
\hline Mean & 17.26578 & 3262.758 & 88.68194 & 22.84290 \\
Median & 25.20997 & 648.4000 & 111.2300 & 22.42000 \\
Maximum & 83.69824 & 13226.00 & 253.4900 & 36.09000 \\
Minimum & -61.18502 & 3.700000 & 1.750000 & 12.00000 \\
Std. Dev. & 30.50783 & 4192.168 & 70.20538 & 4.549640 \\
Skewness & -0.488124 & 0.974297 & 0.212773 & 0.643122 \\
Kurtosis & 3.236337 & 2.496596 & 2.002408 & 4.474158 \\
Jarque-Bera & 1.303183 & 5.231811 & 1.519361 & 4.943943 \\
Probability & 0.521216 & 0.073102 & 0.467816 & 0.084418 \\
Sum & 535.2391 & 101145.5 & 2749.140 & 708.1300 \\
Sum Sq. Dev. & 27921.83 & $5.27 \mathrm{E}+08$ & 147863.9 & 620.9768 \\
No. Obs & 32 & 32 & 32 & 32 \\
\hline
\end{tabular}

Source: Author's Computation using E views 10.0 
The descriptive results on Table 1 reveal that stock market return (SMR) as a proxy for stock market performance averaged 17.27 units over the period of study with a standard deviation of 30.50. Similarly, equities (EQUI) as a proxy for stock market deregulation has a mean value of 3262.758 billion naira and a standard deviation of 4192.168 billion naira for the period of study. Also, exchange rate (EXR) and interest rates as control variables have respective mean values of 88.68 and 22.84 and standard deviations of 70.21 and 4.55 respectively. Also, the result of the Jarque-Bera test of normality showed that all the variables are normally distributed given that their respective probability values are greater than 0.05 level of significance which implies that the variables are normally distributed, as opposed to a situation of not being normally distributed if their probability values were less than 0.05 level of significant.

\section{Analysis of the Effects of Stock Market Deregulation on Stock Market Performance}

The analysis of the effect of stock market deregulation on the performance of the stock market was carried out using ordinary least squared (OLS) techniques and the result of the regression analysis is as presented below;

\section{Dependent Variable: SMR}

\begin{tabular}{lrlll}
\hline \hline \multicolumn{1}{c}{ Variable } & Coefficient & Std. Error & t-Statistic & Prob. \\
\hline \hline \multicolumn{1}{c}{ EQUI } & -0.290442 & 8.308044 & -0.966466 & 0.3439 \\
EXR & 0.823867 & 16.25957 & 0.042688 & 0.5926 \\
INTR & -0.670717 & 35.58758 & -0.131246 & 0.8967 \\
$\quad$ C & 47.90437 & 103.0226 & 0.464989 & 0.6463 \\
\hline \hline & & & & \\
R-squared & 0.714133 & Mean dependent var & 19.98601 \\
Adjusted R-squared & 0.501415 & S.D. dependent var & 30.48964 \\
S.E. of regression & 30.51121 & Akaike info criterion & 9.810019 \\
Sum squared resid & 21411.49 & Schwarz criterion & 10.00200 \\
Log likelihood & -128.4353 & Hannan-Quinn criter. & 9.867104 \\
F-statistic & 0.987751 & Durbin-Watson stat & 1.804346 \\
Prob(F-statistic) & 0.415946 & & \\
\hline \hline
\end{tabular}

The result of the regression analysis revealed that stock market deregulation proxied by equities (EQUI) has negative and statistically insignificant effect on stock market performance in Nigeria. A 1 percent increase in equity will reduce stock market performance by $29.0 \%$. Also, the result indicates that interest rate has a negative and statistically insignificant effect on stock market performance in Nigeria. The findings is contrary to that of Adam and Tweneboah (2008) who examined the impact of macroeconomic variables on stock prices in Ghana using quarterly data from 1991 to 2007. The VECM analysis shows that the lagged values of interest rate and inflation have a significant influence on the stock market. Also, the inward foreign direct investments, oil prices, and the exchange rate demonstrate weak influence on price changes.

On the other hand, exchange rate was found to have positive but statistically significant $(p<0.05)$ effect on stock market performance in Nigeria. The study is in line with that of Serkan (2008) who investigated the role of macroeconomic factors in explaining Turkish stock returns using macroeconomic factor model from the period of July 1997 to June 2005. He found that interest rate and world market return seem to affect all of the portfolio returns, while inflation rate is insignificant for only three of the twelve portfolios.

The value of the R-squared (0.714) indicates that about $51.4 \%$ of the total variation in the dependent variable is explained by the independent variables. Also given that the probability value of the F-statistic $(0.415946)$ is greater than the critical value of 0.05 , the study fails to reject the null hypothesis and concluded that stock market deregulation has no significant effect on stock market performance in Nigeria. Given that the probability value of the equity variable (EQUI) which serves as a proxy for stock market deregulation is (0.3439) which is greater than 0.05 , the study accepts the null hypothesis and concludes that stock market deregulation has no significant effect on stock market performance in Nigeria.

Since the probability value of the exchange rate variable (EXR) is $(0.5926)$ which is greater than 0.05 , the study accepts the null hypothesis and concludes that exchange rate has no significant effect on stock market performance in Nigeria. Since the probability value of the interest rate variable (INTR) is (0.8967) which is greater than 0.05 , the study accepts the null hypothesis and concludes that interest rate has no significant effect on stock market performance in Nigeria. The findings of the study show that stock market deregulation has insignificant effect on stock market deregulation in Nigeria. This implies that deregulating the market will have little or no impact on the market performance. Therefore, efforts to improve the performance of the market be directed to other factors such as the growth of the economy, the efficiency of the market itself and the volume of money in an economy and not just the removal of restrictions. Similarly, both exchange rate and interest rates do not seem to impact significantly on the performance of the market.

\subsection{Conclusion and Recommendations}

\section{Conclusion}

The study revealed that stock market deregulation has no significant effect onstock market performance in Nigeria. This is due to the fact that, the Nigerian stock market is already liberalized as government intervention is already 
minimized to a greater extent. The study therefore concludes that further deregulation of the market will weaken the market and therefore should be avoided.

\section{Recommendation}

The study recommends that since the Nigerian stock market is already liberalized, further deregulations in terms of removal of restrictions will worsen the performance of the market and should be avoided. Similarly, the study recommends evolvement of policies that will bring down the rate of exchange and interest rate in the view of making the naira valuable relative to the dollar and making the cost of capital affordable.

\section{References}

[1].Adam and Tweneboah (2008). Do macroeconomic variables play any role in the stock market movement in Ghana? MPRA working paper No. 9368.

[2].Afees, A.S. and Kazeem, B.A. (2010). The Stock market and economic Growth in Nigeria: An empirical investigation, Journal of Economic Theory 4, 65-70.

[3].Akingbohungbe, S.S. (1996). The Role of the Financial System in the Development of the Nigerian Economy: Paper presented at a workshop organised by centre for Africa law and development studies.

[4].Arestis, P., Demetriades, P. O. and Luintel.

[5].K. B. (2001). Financial Development and Economic Growth: The Role of Stock Markets‘, Journal of Money, Credit and Banking, 33:16-41.

[6].Auzairyn N.A., Ahmad, R. and Ho, S.F. (2011). Stock market deregulation, macroeconomic Variables and stock market performances. International Journal of Trade, Economic and Finance, 2(6), 495-500.

[7].Bilson, C. Brailsford, T. and Hooper, V. (2001). "Selecting macroeconomic variables as explanatory factors of emerging stock market return,” Pacific-Basin Finance Journal, vol. 9, pp. 401- 426

[8].Demirguc-Kunt. A.A. and Levin R. (1996). Stock Market Corporate Finance and Economic Growth: An Overview. The World Bank Review 10(2) 223-225.

[9].Dritsaki C. and M. DritsakiBargiota (2005).The casual relationship between stock, credit market and economic development: An empirical evidence of Greece, Economic change and restricting 38, 113-127.

[10]. Economywatch (2010). Stock Market Performance

[11]. Edame, G .E and Okoro, U (2013).The Impact of Capital Market and Economic Growth in Nigeria: Public Policy and Administration Research, ISSN 2224-5731(Paper) ISSN 2225- 0972(Online) Vol.3, No.9, 2013

[12]. Elumide and Asaolu (2006). Stock Market Capitalization of interest rate in Nigeria: A time series Analysis. Euro Journal Publishing Inc.

[13]. Hoesli, M. \& McGregor, B.D., (2000). Property Investment, Longman, UK.

[14]. Levine, R. and S. Zervos, S. (1996). "Capital control deregulation and stock market development," World Development, vol. 26, pp. 1169-1183

[15]. Osinubi, Tokunbo S. (1998). Stock Market Development and Long-run Growth in Nigeria”. Unpublished M.Sc. Economics Dissertation, University of Ibadan Nigeria.

[16]. Reilly, F.K. \& Brown, K.C., (2003). Investment analysis: portfolio management (Seventh edition) Thomas South Western, Ohio, USA.

[17]. Ross, S. A., Westerfiled R. W. \& Jaffe Jeffrey (2005). Corporate Finance, 7th Ed., New York: McGraw-Hill.

[18]. Serkan, (2008).Stock market in development capital accumulation and growth. The University of West Indies, Trindad.

[19]. Sokpo, S.T., Iorember, P.T. and Usar, T. (2017). Inflation and Stock Market Returns Volatility: Evidence from the Nigerian Stock Exchange 1995Q1- 2016Q4: An E-GARCH Approach. International Journal of Econometrics and Financial Management, 2017, Vol. 5, No. 2, 69-76. 